\title{
COMUNICACIONES
}

\section{Eficacia de cuatro antiparasitarios para el control de Melophagus ovinus en la Región de Magallanes, Patagonia Chilena}

\author{
FRANCISCO ALVAREZ*
}

\author{
EFFICIENCY OF FOUR ANTIPARASITIC FOR Melophagus ovinus CONTROL IN \\ MAGALLANES REGION, CHILEAN PATAGONIA
}

The aim of this study was to evaluate the efficiency of four antiparasitic for the Melophagus ovinus control in the XII Region, Chile. Two dipping and two endectocides were applied in groups of 200 sheared sheeps, realizing in series measurements of morbility and quantifying the parasites number's in ten individuals of every group. Significant differences there are in the parasites number's on the day 56 between the dipping groups and other groups. The parasites death was $100 \%$ from the day 7 until the day 56 post-treatment in the dipping groups. The dipping groups morbility decrease to $0 \%$ from the day 7 and up to the end of this study. One of the relevant conclusion is that the evaluated dippings are $100 \%$ effective in M. ovinus elimination from the day 7 post-treatment.

Key words: Melophagus ovinus, efficiency, control, Chile.

\section{INTRODUCCIÓN}

El Melophagus ovinus o falsa garrapata es un parásito artrópodo obligado de los ovinos, pertenece a la Familia Hippoboscidae (díptero áptero), se alimenta de sangre y realiza todo su ciclo vital, el cual se completa en 24 a 36 días $^{1}$, sobre el animal huésped ${ }^{2}$. La transmisión se produce por contacto directo entre animales, en especial durante los meses cálidos cuando los parásitos adultos se encuentran en la superficie del vellón y se realizan concentraciones de animales o el cordero se encuentra con su madre ${ }^{3}$.

Es el más cosmopolita de los parásitos externos de los ovinos, alcanzando todas las áreas del mundo donde se cría esta especie, en especial las de clima más frío ${ }^{3}$ En Chile, fue descrito en $1974^{4}$ aunque probablemente esté presente desde el ingreso de los primeros ovinos a nuestro país. Las pérdidas que produce $M$. ovinus se expresan fundamentalmente por una disminución en la producción de lana, menor desarrollo del animal joven y reducción en el valor de los cueros ${ }^{3}$.

El control se realiza principalmente mediante la aplicación de antiparasitarios después de la esquila, los cuales deben eliminar a los ejemplares adultos y poseer una acción residual prolongada que permita el control de las pupas ${ }^{3}$.

El presente trabajo tiene como objetivo evaluar la efectividad de cuatro antiparasitarios, para el control del M. ovinus, en la XII Región de Magallanes, Chile.

* Servicio Agrícola y Ganadero, Sector Última Esperanza. 


\section{MATERIAL Y MËTODO}

El presente estudio se realizó durante el verano del año 2007, la población de referencia correspondió a los ovinos presentes en la XII Región de Magallanes, Chile (48³6’ a 56³0' latidud sur, $66^{\circ} 25^{\prime}$ a $75^{\circ} 40^{\prime}$ longitud oeste), siendo la unidad experimental los ovinos hembras mayores de un año y sin parto (borregas), esquiladas y parasitadas con $M$. ovinus, de la Estancia Cerro Guido, Provincia de Última Esperanza.

Para que un individuo sea elegible debió cumplir con los requisitos de unidad experimental, descartándose a los animales enfermos con cualquier otra patología que no sea la estudiada. Se conformaron cuatro grupos de 200 individuos cada uno, que correspondieron a los grupos tratados, más un grupo control de 200 individuos; todos los grupos se ubicaron en potreros diferentes, sin contacto entre ellos, representando lo más fielmente posible, las condiciones de terreno.

\section{Criterio diagnóstico y periodo de seguimiento}

La determinación de parasitismo por $M$. ovinus se realizó posterior a la esquila, mediante inspección visual de la base del vellón, en las áreas de la cabeza, cuello, abdomen, tórax, flancos y entrepierna, con un mínimo de 40 sitios de inspección por animal ${ }^{5}$. Los animales seleccionados ingresaron simultáneamente al ensayo, identificándolos con un autocrotal numerado y registrando en una planilla el número total de parásitos en los primeros 10 animales de cada grupo, en los 190 restantes sólo se determinó presencia o ausencia. Las mediciones se efectuaron los días 7, 14, 28 y 56 posttratamiento (PT), en el mismo potrero en que estaban los animales, para prevenir la posible reinfestación.

\section{Protocolo de administración}

Grupo I: Aplicación día 0 de Rank L.A ${ }^{\odot}$ (ivermectina al 1\% de larga acción) en dosis de 1 $\mathrm{ml}$ vía subcutánea cada $30 \mathrm{~kg}$ de peso vivo (equivalente a $333 \mathrm{mcg} / \mathrm{kg}$ ), en la superficie medial del miembro posterior.
Grupo II: Aplicación día 0 de Abamec L.A. ${ }^{\odot}$ (abamectina al 1\% de larga acción) en dosis de 1 ml vía subcutánea cada $30 \mathrm{~kg}$ de peso vivo (equivalente a $333 \mathrm{mcg} / \mathrm{kg}$ ), en la superficie medial del miembro posterior.

Grupo III: Aplicación día 0 de baño de inmersión con Tipertox ${ }^{\circledR}$ (cipermetrina-diazinón), en una concentración de $145 \mathrm{ml}$ cada $200 \mathrm{~L}$ de agua y una recarga de $145 \mathrm{ml}$ cada $100 \mathrm{~L}$ de agua.

Grupo IV: Aplicación día 0 de baño de inmersión con Sarnacuran 50 EC ${ }^{\circledR}$ (Phoxim), en una concentración de $750 \mathrm{ml}$ cada $1.000 \mathrm{~L}$ de agua, recarga de $750 \mathrm{ml}$ cada $500 \mathrm{~L}$ de agua.

Grupo V: Control, sin aplicación de productos.

\section{Análisis estadísticos}

Para determinar diferencias entre el número de parásitos de cada grupo, luego de descartar una distribución normal de los datos, se realizó el test de Kruskal Wallis para medianas, en el caso de existir diferencias se realizó el test de Mann Whitney entre cada uno de los grupos, aplicándose la corrección de Bonferroni para comparaciones múltiples. Adicionalmente se estimó el porcentaje de disminución del número de melófagos de acuerdo a la fórmula de Henderson-Tilton ${ }^{6}$.

Para el caso de las tasas de morbilidad primeramente se realizó la prueba de $\chi^{2}$ entre cada uno de los grupos, aplicando posteriormente la corrección de Bonferroni.

\section{RESULTADOS}

La carga media inicial de parásitos fue baja en todos los grupos, siendo máxima en el grupo control (media $=5,9$ parásitos por animal); a partir del día 7 PT existieron diferencias significativas entre todos los grupos tratados y el grupo control; al día 56 se encontraron diferencias significativas entre los grupos III, IV y los grupos control, I, II (Tabla 1). El porcentaje de disminución en el número de parásitos al día 7 PT fue de $100 \%$ en los grupos III y IV, el cual se mantuvo hasta la finalización del ensayo, el día 56 (Tabla 2); de la misma forma no existieron animales parasitados en estos grupos a partir del

\footnotetext{
Laboratorio Intervet Chile Ltda., San Pío X N² 460 of. 808, Providencia, Santiago, Chile. Laboratorio Brower, Dr. Rafael Bielsa 238 (1427), Capital Federal, Buenos Aires, Argentina.

(a) Laboratorio Bayer S.A. Chile, Carlos Fernández N² 260, San Joaquín, Santiago, Chile.
} 
Tabla 1. Mediana y media del número de parásitos según grupo de tratamiento. XII Región, Chile, 2007

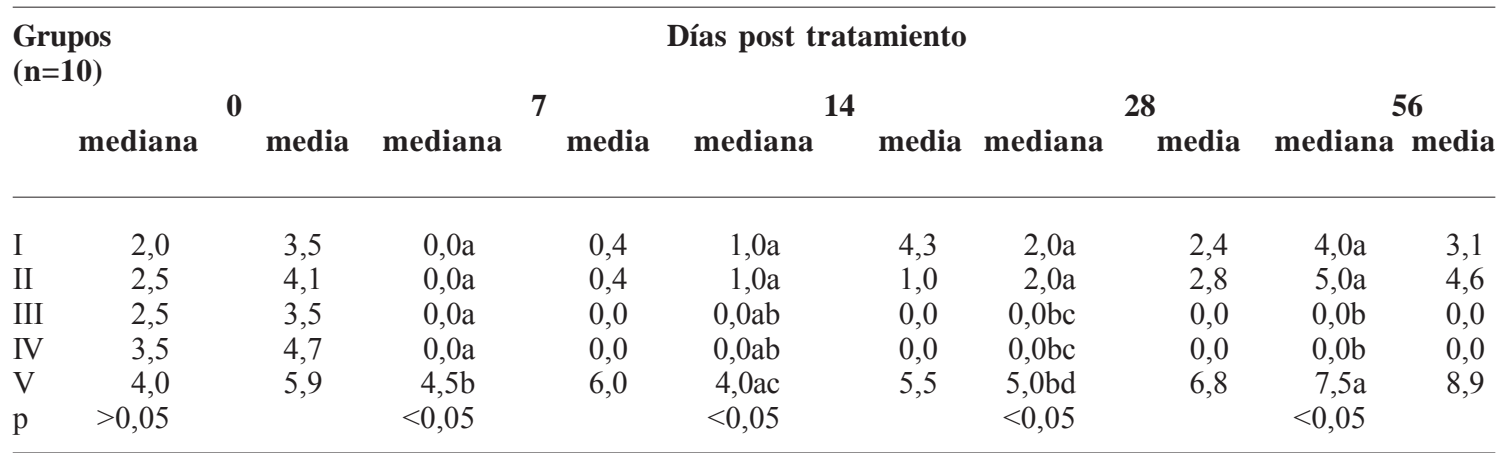

Letras diferentes en la columna indican diferencias significativas $(\mathrm{p}<0,05)$.

Fuente: Servicio Agrícola y Ganadero (SAG).

Tabla 2. Porcentaje de disminución del número de melófagos según grupo de tratamiento fórmula de Henderson-Tilton. XII Región, Chile, 2007

\begin{tabular}{|c|c|c|c|c|}
\hline \multicolumn{2}{|c|}{$\begin{array}{r}\text { Grupos } \\
(n=10)\end{array}$} & \multicolumn{3}{|c|}{ Días Post tratamiento } \\
\hline & 7 & 14 & 28 & 56 \\
\hline & $\%$ & $\%$ & $\%$ & $\%$ \\
\hline I & 92,4 & 53,6 & 64,7 & 65,2 \\
\hline II & 92,2 & 87,4 & 51,8 & 39,5 \\
\hline III & 100,0 & 100,0 & 100,0 & 100,0 \\
\hline IV & 100,0 & 100,0 & 100,0 & 100,0 \\
\hline
\end{tabular}

Fuente: SAG.

día 7 PT manteniéndose en dicho nivel de morbilidad hasta el día 28 (Tabla 3), fecha en que concluyó la medición de este parámetro, debido a la baja disponibilidad de forraje en los lugares en donde se encontraban los animales.

\section{DISCUSIÓN}

Existió coincidencia entre los resultados obtenidos y otros trabajos que demuestran el $100 \%$ de efectividad de los organofosforados en baños de inmersión aplicados en diferentes concentraciones $^{7,8}$, sin embargo, debido a que no poseen efecto residual y por lo tanto no logran controlar las pupas, se describe que se debe repetir el tratamiento. Entre los factores que probablemente facilitaron el éxito del tratamiento se destacan la baja infestación y el
Tabla 3. Tasa de morbilidad según grupo de tratamiento. XII Región, Chile, 2007

\begin{tabular}{lcccr}
\hline $\begin{array}{c}\text { Grupos } \\
(\mathbf{n = 2 0 0 )}\end{array}$ & \multicolumn{4}{c}{ Días Post tratamiento } \\
& $\mathbf{0}$ & \multicolumn{7}{c}{} & $\mathbf{1 4}$ & $\mathbf{2 8}$ \\
& $\%$ & $\mathbf{\%}$ & $\mathbf{\%}$ & $\mathbf{\%}$ \\
\hline I & 100,0 & $11,8 \mathrm{a}$ & $31,3 \mathrm{a}$ & $65,5 \mathrm{a}$ \\
II & 100,0 & $12,1 \mathrm{a}$ & $43,3 \mathrm{a}$ & $67,6 \mathrm{a}$ \\
III & 100,0 & $0,0 \mathrm{~b}$ & $0,0 \mathrm{~b}$ & $0,0 \mathrm{~b}$ \\
IV & 100,0 & $0,0 \mathrm{~b}$ & $0,0 \mathrm{~b}$ & $0,0 \mathrm{~b}$ \\
V & 100,0 & $85,8 \mathrm{c}$ & $64,7 \mathrm{c}$ & $100,0 \mathrm{c}$ \\
p & & $<0,05$ & $<0,05$ & $<0,05$ \\
\hline
\end{tabular}

Letras diferentes en la columna indican diferencias significativas $(\mathrm{p}<0,05)$. Fuente: SAG.

baño inmediato posterior a la esquila, el cual permite una gran eliminación de la carga parasitaria ${ }^{9}$. Adicionalmente, la mezcla sinérgica organofosforado-piretroide (diazinón-cipermetrina), es descrita como una alternativa para evitar el desarrollo de resistencia parasitaria ${ }^{10,11}$.

El escaso efecto de las lactonas macrocíclicas (ivermectina y abamectina), independiente se su formulación larga acción, se debió probablemente a que los niveles y/o la permanencia del endectocida en el plasma no lograron concentraciones adecuadas $^{12}$. Por este motivo, se recomienda una segunda aplicación a los 20 días $^{9}$, con la salvedad de que este intervalo de tiempo fue determinado en un área geográfica más cálida, razón por la cual, considerando la termodependencia del ciclo del parásito ${ }^{3,13,14}$, se debiera estimar el lapso adecuado para la zona austral de 
Chile, debido a sus temperaturas más bajas.

De acuerdo con lo obtenido en el presente trabajo se puede concluir que los baños de inmersión Tipertox ${ }^{\circledR}$ y Sarnacuran ${ }^{\circledR}$ aplicados posterior a la esquila son eficaces en la eliminación del $100 \%$ de los parásitos M. ovinus a partir del día 7 post-tratamiento.

\section{RESUMEN}

El objetivo del estudio fue evaluar la efectividad de cuatro antiparasitarios para el control del Melophagus ovinus en la XII Región. Se aplicaron dos baños de inmersión y dos endectocidas en grupos de 200 ovinos esquilados, realizando mediciones seriadas de morbilidad en la totalidad de los animales y cuantificando el número de parásitos en diez individuos de cada grupo. Existieron diferencias significativas en el número de parásitos al día 56 entre los grupos bañados y los demás grupos. La disminución en los parásitos fue de $100 \%$ desde el día 7 y hasta el día 56 post-tratamiento en los grupos bañados. La morbilidad de los grupos bañados disminuyó a $0 \%$ desde el día 7 y hasta el término del ensayo. Como conclusión se destaca que los dos baños de inmersión probados son eficaces en la eliminación del 100\% de Melophagus ovinus desde el día 7 post-tratamiento.

\section{REFERENCIAS}

1.- EVANS G O. Studies on the bionomics of sheep ked, Melophagus ovinus L., in west Wales. Bull Ent Res 1950; 40: 459-78.

2.- ROMANO A, CARRERAS F, PRIETO F. Dípteros perjudiciales para el ganado en Argentina. Rev Med Vet 1992; 6: 3-23.

3.- BULMAN G M, LAMBERTI J C. La falsa garrapata del ovino (Melophagus ovinus, L. 1758) (Diptera: hippoboscidae), ectoparásito de creciente importancia económica en la patagonia argentina. Manual técnico,
Asociación Argentina de Parasitología Veterinaria, Buenos Aires, Argentina. 90 p. 2001.

4.- OBERG C, DÍAZ L, VALENZUELA G. Parásitos identificados en bovinos, ovinos, suinos y equinos en el laboratorio de Enfermedades Parasitarias, Escuela de Medicina Veterinaria, Universidad Austral de Chile. Bol Chile Parasitol 1974; 29: 99-102.

5.- HOLDSWORTH P A, VERCRUYSSE J, REHBEIN S, et al. World Association for the Advancement of Veterinary P arasitology (W.A.A.V.P.) guidelines for evaluating the efficacy of ectoparasiticides against biting lice, sucking lice and sheep keds on ruminants. Vet Parasitol 2006; 136: 45-54.

6.- HENDERSON C F, TILTON E W. Tests with acaricides against the brown wheat mite. J Econ Entomol 1955; 48: 157-61.

7.- HEATH A C G, MILLAR S. Some recent insecticides: their efficacy as plunge dips against the biting louse Damalinia ovis and ked Melophagus ovinus, on sheep. N Zeal Vet Jnal 1970; 18: 211-3.

8.- HENDERSON D. Alternative methods of ectoparasite control on sheep. Proceedings of the Sheep Veterinary Society, 1993-1995, Edimburgh, UK 1995; 18: 25-6.

9.- OLAECHEA F, BENITEZ USHER C, CRAMER L G, EAGLESON J S. Efficacy and persistent effect of ivermectin in controlled-release capsule and ivermectin $1 \%$ injection against Melophagus ovinus. WAAVP 16 ${ }^{\text {th }}$. Intl. Conference, Sun City, R. South Africa 1997. Poster 251.

10.- MOTTIER L, LANUSSE C. Bases moleculares de la resistencia a fármacos antihelmínticos. Rev Med Vet (B. Aires) 2001; 82: 74-85.

11.- OLAECHEA F. Ecto y endoparásitos, epidemiología y control. Seminario de Actualización en ovinos. INTA Bariloche, Septiembre 2005. Disponible en: w w w. p r o d u c c i o n b o vi n a c o m/ sanidad intoxicaciones metabolicas/parasitos/ parasitos_ovinos/01-ecto_y_endoparasitos.pdf (Consultado el 03/04/2007).

12.- GUERRERO MOLINA C. Comparative activity of ivermectin given by the subcutaneous and oral routes in sheep naturally infested with $M$. ovinus. Vet Mex 1986; 17: 41-3.

13.- BORCHERT A. Parasitología Veterinaria. Ed. Acribia, España, 1975; 576-8.

14.- SOULSBY E J L. Parasitología y enfermedades parasitarias de los animales domésticos. $7^{\mathrm{a}}$ edición, Interamericana, México DF, 1987; 439-41.

\footnotetext{
Correspondencia a:

Francisco Alvarez

I. Carrera Pinto $\mathrm{N}^{\circ}$ 566, Puerto Natales, Chile.

Fono: (61)411443 - 410732.

E-mail: francisco.alvarez@sag.gob.cl
} 


\title{
COMUNICACIONES
}

\section{Immunoparasitological diagnosis of Strongyloides stercoralis in garbage collectors in Uberlândia, MG Brazil.}

\author{
ELEUZA R.MACHADO*, ELIANE M. TEIXEIRA*, FABIANA M. DE PAULA*, \\ MARIA R F GONÇALVES-PIRES*, MARLENE T. UETA** and JULIA M. COSTA-CRUZ*
}

\begin{abstract}
The objective of this study was to determine the presence of Strongyloides stercoralis in urban garbage collectors through the use of immunological and parasitological methods. A total of 92 individuals were evaluated from August, 1997, to June, 1998. For the parasitological diagnosis Baermann and Lutz' methods were applied. The immunological diagnosis involved the indirect fluorescence antibody test (IFAT) and the enzyme-linked immunosorbent assay (ELISA) to detect specific IgG antibodies. Of the 92 workers examined, six (6.5\%) were infected with larvae of $\boldsymbol{S}$. stercoralis. The IFAT detected 19 (16.3\%) and the ELISA 17 (18.5\%) positive serum samples. The differences between the results of parasitological and immunological methods were statistically significant $(p<0.05)$. These results demonstrate that there is a need to improve the health conditions of this category of city employees.
\end{abstract}

Key words: Strongyloides stercoralis, Garbage collectors, Intestinal parasites, Brazil.

\section{INTRODUCTION}

Strongyloidiosis is caused by a geohelminth, Strongyloides stercoralis occurring worldwide and particularly in tropical regions ${ }^{1,2}$. Although the disease is manifested in most cases as chronic and asymptomatic, potentially fatal outcomes may occasionally occur, especially among individuals with immunosuppression ${ }^{3,4}$.

In spite of the elevated incidence of intestinal parasites, including S. stercoralis, in the city of Uberlândia, as well as the characterization of Uberlândia as a hyper-endemic region in terms of strongyloidiasis, there is an absence of studies on parasitosis among public employees. Thus, the objective of the present study was to investigate the presence of S. stercoralis among garbage collectors in Uberlândia, MG, Brazil, using parasitological and immunological methods.

\section{MATERIALS AND METHODS}

Uberlândia is the center of a macro-region, the "Triângulo Mineiro", with 500.095 habitants. In 1997, the city had 410 employees working in the public sanitation system. The present study was conducted among 92 individuals, randomly selected between August, 1997, and June, 1998, with previous written authorization and completion of identification files. Fecal and blood samples were collected and processed in the parasitological laboratory of the Federal University

\footnotetext{
* Instituto de Ciências Biomédicas, Universidade Federal de Uberlândia, Uberlândia, MG, Brasil.

** Instituto de Biologia, Universidade Estadual de Campinas, Campinas, SP, Brasil.
} 
of Uberlândia, MG.

For the parasitological diagnosis, fresh fecal samples were collected on consecutive days. These samples were examined using the Baermann ${ }^{5}$ and Lutz ${ }^{6}$ methods. For each method eight separate tests were conducted. The total number of 4,416 slides were thus examined. When the parasitological stool examination was positive the workers was informed and referred for medical treatment.

The immunological diagnosis to detect IgG anti S. stercoralis antibodies was realized in serum samples by the indirect fluorescent antibody test

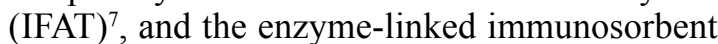
assay (ELISA) ${ }^{8}$, using slides containing sections of filariod and alcalin larval extract of $S$. venezuelensis.

The results were expressed as antibody titers, considered positive when $\geq 20$ by IFAT or $\geq 80$ by ELISA. Reactive serum samples were retested in two fold serial dilutions up to the end-point titer. The results of the parasitological and immunological methods were analyzed using Fisher's test with $\mathrm{p}<0.05$.

\section{RESULTS AND DISCUSSION}

The mean age of the participants in the study was 49 years (28 - 70 years), 40 (43.5\%) individuals were male and $52(56.5 \%)$ female. Parasitological results revealed six $(6.5 \%)$ cases of S. stercoralis, confirmed that the region of Uberlândia as endemic ${ }^{9-11}$.

Serological methods have been found to be helpful for the diagnosis of strongyloidiasis $7,8,10,12$. Of the 92 serum samples examined, 17 (18.5\%) were positive for $S$. stercoralis by immunological methods, $15(16.3 \%)$ were positive by IFAT and $17(18.5 \%)$ by ELISA. The parasitological and immunological results are demonstrated in Table 1. Although significant differences were found between the parasitological and immunological results using the two methods ( $p$ $<0.05$ ), all of the six individuals with positive parasitological results for $S$. stercoralis were also found to be positive by both immunological methods. Results demonstrated that $52.9 \%$ of the cases using reagents for the identification of S. stercoralis were females.

Related studies on the occurrence of intestinal parasites in workers exposed to sewage have demonstrated the occupational risk of intestinal infection $^{13,14}$. Between July, 1997 and December, 1998 a study of infections by parasites was conducted among street people in Rio de Janeiro, Brazil. The results included Ascaris lumbricoides

Table 1. Characterization of the positive cases of Strongyloides stercoralis in terms of age and sex using two parasitological and immunological methods to examine garbage collectors in Uberlândia, MG, Brazil

\begin{tabular}{|c|c|c|c|c|}
\hline Age (years) & Sex & Parasitological methods & IFAT & ELISA \\
\hline 67 & M & S. stercoralis & 80 & 80 \\
\hline 46 & $\mathrm{~F}$ & S. stercoralis & 160 & 640 \\
\hline 48 & $\mathrm{M}$ & S. stercoralis & 20 & 160 \\
\hline 36 & $\mathrm{~F}$ & S. stercoralis & 40 & 320 \\
\hline 47 & M & S. stercoralis & 20 & 160 \\
\hline 59 & M & S. stercoralis + hookworm & 160 & 640 \\
\hline 37 & $\mathrm{M}$ & Giardia lamblia & 20 & 320 \\
\hline 52 & $\mathrm{~F}$ & Negative & 20 & 160 \\
\hline 54 & M & Negative & 20 & 320 \\
\hline 40 & $\mathrm{~F}$ & Negative & 20 & 320 \\
\hline 53 & $\mathrm{M}$ & Negative & Negative & 640 \\
\hline 49 & $\mathrm{M}$ & Negative & Negative & 320 \\
\hline 40 & $\mathrm{~F}$ & Negative & 40 & 160 \\
\hline 54 & $\mathrm{~F}$ & Negative & 40 & 320 \\
\hline 36 & $\mathrm{~F}$ & Negative & 20 & 320 \\
\hline 58 & M & Negative & 20 & 320 \\
\hline 34 & $\mathrm{~F}$ & Negative & 40 & 160 \\
\hline
\end{tabular}

F: female; M: male. IFAT: Indirect fluorescence antibody test, ELISA: enzyme-linked immunosorbent assay. The results were expressed as antibody titers. 
in $48.85 \%$, Thichuris trichiura in $32.9 \%$ and hookworm in $8.5 \%$ of the participants suggesting the potential contamination of public areas in the locale ${ }^{15}$. The contact with garbage may, thus, be associated with such risks as intestinal parasites, especially when the protective equipment is not used adequately. It is, thus, not surprising that public workers in this area had acquired strongyloidiasis and demonstrated positive results for S. stercoralis by the immunological tests applied. The results also suggest that the detection of specific antibodies of S. stercoralis by IFAT and ELISA tests may contribute to the diagnosis of strongyloidiasis, principally as complementary parasitological methods.

The present study of strongyloidiasis in garbage collectors is significant in terms of offering evidence of the health situation of workers as well as to suggest a method for screening them for participation in programs to control intestinal parasites.

\section{REFERENCES}

1.- CONCHA R, HARRINGTON J R W, ROGERS A L. Intestinal strongyloidiasis: recognition, management and determinants of outcome. J Clin Gastroenterol 2005; 39: 203-11.

2.- SIDDIQUI A A, BERK S L. Diagnosis of Strongyloides stercoralis infection. Clin Infect Dis 2001; 33: 10407.

3.- FERREIRA M. Strongyloidiasis and acquired immunodeficiency syndrome. Enf Emerg 2003; 5: 1826.

4.- VADLAMUDI RS, CHI D S, KRISHANASWAMY G. Intestinal strongyloidiasis and hyperinfection syndrome. Clin Mol Allergy 2006, 4: 1-13.

5.- BAERMANN G. Eine Einfache methode zur auffindung von Ankylostomum (Nematoden) larven in Erdproben.
Mededeel mit h. Geneesk Lab Weltvreden Feestbundel, Batavia, 1917, p. 41-7.

6.- LUTZ A V. Schistosoma mansoni e a schistosomose, Segundo observações feitas no Brasil. Mem Inst Oswaldo Cruz 1919; 11: 121-5.

7.- COSTA-CRUZ J M, BULLAMAH CB, GONÇALVEZPIRES M R F, et al. Cryo-microtome sections of coproculture larvae of Strongyloides stercoralis and Strongyloides ratti as antigen sources for the immunodiagnosis of human strongyloidiasis. Rev Inst Med Trop São Paulo 1997; 39: 313-7.

8.- MACHADO E R, UETA M T, GONÇALVES-PIRES M R F, et al. Strongyloides venezuelensis alkaline extract for the diagnosis of human strongyloidiasis by enzyme-linked immunosorbent assay. Mem Inst Oswaldo Cruz 2003; 98: 849-53.

9.- MACHADO E R, COSTA-CRUZ J M. Strongyloides stercoralis and other enteroparasites in children at Uberlândia City, state of Minas Gerais, Brazil. Mem Inst Oswaldo Cruz 1998; 93: 161-4.

10.- PAULA F M, CASTRO E, GONÇALVES-PIRES M R $\mathrm{F}$, et al. Parasitological and immunological diagnoses of strongyloidiasis in immunocompromised and nonimmunocompromised children at Uberlândia City, state of Minas Gerais, Brazil. Rev Inst Med Trop São Paulo 2000; 42: 51-5.

11.- OLIVEIRA L C M, RIBEIRO C T, MENDES D M, et al. Frequency of Strongyloides stercoralis in alcoholics. Mem Inst Oswaldo Cruz 2002; 97: 119-21.

12.- LINDO J F, CONWAY D J, ATKINS N S, et al. Prospective evaluation of enzyme-linked immunosorbent assay and immunoblot methods for the diagnosis of endemic Strongyloides stercoralis infection. Am J Trop Med Hyg 1994; 51: 175-9.

13.- CLARK C S, LINNEMANN C C Jr, CLARK J G, et al. Enteric parasites in workers occupationally exposed to sewage. J Occup Med 1984; 26: 273-5.

14.- SCHLOSSER O, RALL D, LAURECEAU M-N. Intestinal parasite carriage in workers exposed to sewage. Eur J Epidemiol 1999; 15: 261-5.

15.- GOMES T C, ALMEIDA M F, MUIRA L A, et al. Helmintoses intestinais em população de rua da cidade do Rio de Janeiro. Rev Soc Bras Med Trop 2002; 35: 531-2.
Correspondencia a:

Julia Maria Costa-Cruz

Laboratório de Parasitologia, Instituto de Ciências Biomédicas, Universidade Federal de Uberlândia, Uberlândia, MG, Brasil, Avenida Pará, n. 1720, 38400 902, Uberlândia, MG, Brasil. Fone (51) 3432182187. costacruz@ufu.br. 